\title{
O ENFOQUE DOUTRINÁRIO NO DIREITO CONSTITUCIONAL COMPARADO: LIÇÕES CLÁSSICAS E CONTEMPORÂNEAS
}

\author{
THE DOCTRINAL APPROACH IN COMPARATIVE CONSTITUTIONAL LAW: \\ CLASSICAL AND CONTEMPORARY LESSONS
}

Gabriel Lima Marques

\begin{abstract}
Doutorando em Direito Público na Universidade do Estado do Rio de Janeiro UERJ. Mestre em Direito pela Universidade Federal do Rio de Janeiro - UFRJ. PósGraduado em Direito e Saúde pela Escola Nacional de Saúde Pública Sérgio Arouca ENSP da Fundação Oswaldo Cruz - FIOCRUZ. Bacharel em Direito pela Universidade do Estado do Rio de Janeiro - UERJ. Professor (40 horas - DE) de Direito Constitucional da Universidade Federal do Amapá - UNIFAP. Advogado.

E-mail: gabriel-marques@hotmail.com
\end{abstract}

Recebido em: 22/03/2017

Aprovado em: 27/11/2017

\begin{abstract}
RESUMO: O presente trabalho tem por escopoapresentar em linhas gerais os pontos que os estudiosos do direito constitucional comparado de hoje e de antes, entendem como aqueles que encerram os problemas fundamentais deste campo. Preliminarmente,porém, e seguindo o exemplo do que faziam muitos dos juristas do período clássico, será exposta uma breve síntese da discussão sobre o estatuto epistemológico do direito comparado, chamando-se a atenção para como esse debate foi internalizado no campo em tela pelos referidos autores. Na sequência, serão trazidas aindatanto algumas colocações em relação aos principais impasses quenutriram as querelas acadêmicas do direito constitucional comparado no passado, quais sejam: os questionamentos a respeito do para que se compara, o que se compara, e como se deve comparar. Quanto serão oferecidas colocações sobre temas afetos ao direito constitucional comparado do momento atual, ocasião em que se disponibilizará o que vem sendo objeto de consideraçãodos diferentes especialistas hodiernamente, de modo específico, sobre: porque, quando, e de que forma, os tribunais os juízes se utilizam ou deveriam se utilizar de referências constitucionais alienígenas.
\end{abstract}

Palavras-Chave: Direito Comparado; Constituição;Doutrina.

ABSTRACT: The present work aims to present in general lines the points that the scholars of comparative constitutional law of today and before, understand as those that contain the fundamental problems of this field. Preliminarily, however, and following the example of many of the jurists of the classical period, a brief summary of the discussion on the epistemological status of comparative law will be exposed, drawing attention to how this debate was internalized in the field in question by the aforementioned Authors. In the sequence, there will be brought up, as well some placements in relation to the main impasses that nourished the academic quarrels of constitutional law compared in the past, namely: the questions about why to compare, what to compare and how compare. And will be offered placements on subjects related to the comparative constitutional law of the current moment, occasion in which will be made available what is being object of consideration of the different specialists nowadays, specifically, on: why, 
when, and in what form, the courts o the judges use or should use alien constitutional references. Keywords: Comparative Law; Constitution; Doctrine.

SUMÁRIO: Introdução; 1. Entre o Método e a Ciência Autônoma: o embate preliminar do comparativismo lato e sua presença nos domínios do clássico direito constitucional comparado; 2. O Direito constitucional comparado tradicional e seus principais impasses: uma mirada elucidativa a partir da Doutrina; 3. O Direito constitucional comparado hodierno: inquietações de um novo rumo; Conclusão; Referência Bibliografica.

\section{INTRODUÇÃO}

Embora não se possa afirmar que a citação realizada pelos magistrados a experiências não-nacionais no processo de fundamentação de suas decisões, seja um fenômeno novo, é certo que no âmbito da jurisdição constitucional tal recurso somente passou a ter uma utilização mais intensa com o desenrolar dos últimos anos. Isso se deve em grande medida a confluência entre a facilidade de acesso e de troca de informações provocadas pela globalização, como, de igual modo, em virtude da proliferação no fim do século XX e início do século XXI, de novos processos constituintes em vários países. Tal contexto acabou por gerar um progressivo aumento da circulação de práticas, ideias, modelos e fontes, e como consequência direta, as cartas políticas passaram a ter uma dependência constante de referências comparadas em todas as fases de seu ciclo de vida, desde o momento ainda de sua edição, de seu desenho, passando igualmente pela derradeira etapa da sua aplicação pelos membros de uma suprema corte qualquer.

Ocorre que como unido a esta tendência visualizada em escala global, surgiram também inúmeras e novas questões a seu respeito, não demorou tanto até que se operasse um redirecionamento dos trabalhos acadêmicos no sentido de se procurar oferecer a elas algumas respostas. Tal peculiaridade, aliás, é o que nos permite, inclusive, falar aqui na existência de um novo direito constitucional comparado. Isso por que, embora esta disciplina seja herdeira de uma tradição que remonta desde muito. Nos dias correntes a mesma tem se diferenciado de sua vertente, a que chamamos de clássica, justamente pelo fato de que nesta, quase nenhuma atenção se voltou no curso de se refletir sobre o uso do arcabouço alienígena por cortes constitucionais (MARQUES, 2014). Assim sendo, eis, portanto, o pano de fundo que conferiu a direção que será trilhada por este paper, qual seja:apresentar,a partir da leitura dos trabalhos produzidos pelos principais autores que formam cada um dos dois grupos, os pontos que compõem as preocupações teóricas mais básicastanto da vertente clássica do direito constitucional comparado, quanto de sua tendência de matriz contemporânea. Como, porém, a discussão sobre se o direito comparado é um método ou uma ciência autônoma sempre foi algo presente nos estudos do direito constitucional comparado clássico. Também este paper não poderia deixar de se iniciar pela apresentaçãodo estado da arte desse ponto, antes mesmo de adentrar em seu objetivo.

\section{ENTRE O MÉTODO E A CIÊNCIA AUTÔNOMA: O EMBATE PRELIMINAR DO COMPARATIVISMO LATO E SUA PRESENÇA NOS DOMÍNIOS DO CLÁSSICO DIREITO CONSTITUCIONAL COMPARADO}

Para os comparativistas em geral, dentre os maiores dilemas teóricos até hoje enfrentados, sem dúvidas o que mais teve destaque foi o que girou em torno da célebre discussão sobre se o Direito comparado trata-se de um método ou de uma ciência (CAÑIZARES, 1954, p. 49). Aliás, por um considerável período de tempo, as atenções se voltaram quase que na sua inteireza para este tópico. Passada, porém, a etapa das discussões apaixonadas, conforme assevera LeontinConstantinesco (1998, p. 280), é possível atualmente agrupar os posicionamentos dos autores em pelo menos três correntes diversas. Neste sentido, houve quem 
afirmasse que esta disputa somente interessava ao meio acadêmico e, justamente por isso, não merecia ser prolongada. Outros que por sua vez abordaram o problema se pronunciando decididamente a favor do primeiro termo do dilema, isto é, sustentando que o direito comparado nada mais era do que um método. E por último, os que entendiam justamente o contrário, quer dizer, os que assumiram a condição do direito comparado enquanto também, uma ciência autônoma.

No que se refere ao primeiro juízo, o qual, aliás, trata-se do mais recente deles, ${ }^{1}$ a argumentação medular que compartilham seus adeptos é a de que, em sendo a controvérsia sobre a natureza do Direito comparado uma disputa de cunho meramente teórico, não haveria como consequência direta, qualquer importância prática em se levar a mesma adiante. Tal posicionamento, cujas origens remontam a reação desencadeada, sobretudo, por autores anglosaxões que viam com certa desconfiança a polêmica em torno do presente debate, congrega em seu bojo, não só uma relevante parte de autores, quanto tem como seus principais expoentes, importantes nomes do comparativismo em geral, dentre eles, Felipe Cañizares e Clive Schmithoff (CONSTANTINESCO, 1998, pp. 281-284).

De outro modo, porém, sustentam juristas igualmente conhecidos, como Rudolf Schlesinger, TullioAscarelli e René David, ser o Direito comparado nada mais do que uma mera técnica. Quer dizer, para estes, uma ciência especial do Direito comparado não existe nem muito menos poderia vir a existir, visto que se está lidando unicamente com um método de pesquisa científica aplicado a uma disciplina, essa sim autônoma, que por sua vez objetiva alcançar seus próprios fins. Deste modo, reconhece-se, portanto, a infelicidade da expressão "Comparative Law" larga e comumente utilizada (GUTTERIDGE, 1949, p. 01). Isso porque a mesma, em total contradição com o que postulam os partidários supracitados, traz junto de si a percepção de que designa um corpo de normas individuais realizadas através do cotejamento, fato que por consequência permitiria ao Direito comparado avocar o reconhecimento de ser também parte das muitas vertentes do campo jurídico. No entanto, consoante o raciocínio empregado pelos defensores do entendimento em tela, tal acepção não se revelaria nem um pouco aceitável, vez que para os mesmos, há aqui a ausência de um verdadeiro independentbodyofrules, tal qual existe, por exemplo, no caso do direito de família e em tantos outros (CONSTANTINESCO, 1998, p. 293). ${ }^{2}$

Por seu turno, e na outra extremidade, entre aqueles que tomam o Direito comparado enquanto ciência, vale a menção de que as direções dadas no sentido de corroborar tal posição, foram senão múltiplas, certamente, e em algumas ocasiões, contraditórias. ${ }^{3}$ Neste sentido, eis a

\footnotetext{
${ }^{1}$ Isso por que, conforme salienta Marc Ancel (1980, p. 47), esta corrente é a representação de um grupo de teorias críticas surgido após 1945, e que partiam de uma dupla constatação, a de que após cinquenta anos, ainda não se conseguira formular uma definição de direito comparado aceita por todos, e a de que as discussões metodológicas sobre a função, a natureza e a posição do Direito comparado, resultaram apenas em uma grande confusão.

${ }^{2}$ LeontinConstantinesco (1998, pp. 292-293), contudo, destaca ser “[...] evidente, por exemplo, que enquanto a comparação serve a uma outra disciplina autônoma, ela não pode pretender ser, por sua vez, uma ciência independente. Da mesma forma, é igualmente exato afirmar que o método comparativo é, antes de tudo, um método, portanto, um instrumento. Todavia, tais afirmações não resolvem o dilema porque, na realidade, o problema não está aí. Na verdade, a questão relativa à existência de uma ciência autônoma deve ser avaliada em função de um campo de investigação que lhe pertence de modo exclusivo e que, justamente, se diferencia dos âmbitos das outras disciplinas. Uma ciência pode pretender a autonomia na medida em que, colocando novos problemas, logra novos conhecimentos integrados em um todo coerente. Ordenando as noções e classificando os resultados, ela resolve os quesitos colocados e faz progredir a sabedoria humana em um campo no qual nenhuma outra ciência ainda o fez $[\ldots]$...

Neste plano em particular, LeontinConstantinesco (1998, p. 296) salienta que “[...] não obstante as aparências contrárias, todos os comparatistas pertencentes a essa corrente estão de acordo sobre um ponto: o fato de que o direito comparado é simultaneamente método e ciência. Este duplo caráter é afirmado de modo explícito somente por alguns, porém, de fato, é aceito de forma tácita por todos. Não existe qualquer teoria que defenda a ideia de que o Direito comparado é somente uma ciência autônoma e não, ao mesmo tempo, um método [...]".
} 
razão do porque se perceber entre os estudiosos que se inserem neste grupo, uma particular fluidez entre as fronteiras das opiniões por eles apresentadas. Afinal, em um trajeto marcado pela imprecisão, não se revela insólita a geração de uma profunda celeuma de razões argumentativas. Desta forma, de uma parte, isso faz com que qualquer classificação seja delicada, já que essa necessariamente, e com os riscos que comporta, obriga a fazer simplificações. Além do que, de outro modo, torna igualmente difícil agrupar os autores que em sua grande maioria procuram caminhar tanto por direções diversas, quanto e por quase sempre em outras possíveis dimensões do que se entende enquanto científico (CONSTANTINESCO, 1998, pp. 295-296).

Todavia, muito embora se reconheça a controvérsia em tal contexto, com o intuito de auxiliar ao menos na compreensão de tais posicionamentos, os mesmos são passíveis de serem resumidos do seguinte modo: há os que consideram o Direito comparado autônomo, seja como disciplina $;{ }^{4}$ ou ainda enquanto ciência stricto sensu $;{ }^{5}$ os que reconhecem a ele uma pluralidade de objetivos, conteúdo e campo de aplicação; ${ }^{6}$ os que afirmam ser ele um método suscetível de evoluir, algumas vezes em ciência, como por exemplo, haveria ocorrido com a filosofia do Direito; ${ }^{7}$ outros que assumem ser este um dos inúmeros ramos da ciência comparativa geral, da qual pertencem, dentre outros, a linguística; ${ }^{8}$ e por fim, aqueles que entendem ainda, que na verdade, o que existe é uma estreita relação entre este, e uma concepção jurídica universalista, ou seja, o Direito comparado ao contribuir para construção de um Direito tido como mundial estaria, por conseguinte, emancipado (CONSTANTINESCO, 1998, pp. 297-320). ${ }^{9}$

Ocorre que diante de tal quadro, no qual como se percebe, existe uma vultuosidade tamanha de opiniões conflitantes e especulativas não demorou até que muitos dos pesquisadores que se aventuravam pelas paragens do cotejamento se perdessem em verdadeiras elucubrações, que no longo prazo, acabaram por encaminhá-los a um nível de abstração e de cansaço intelectual sem precedentes. Neste ambiente, como era de se esperar, inclusive pela dificuldade de compreendê-la e por ser parcamente convidativa e consensual, a controvérsia pouco a pouco foi cedendo o seu grau de intensidade e de importância até ser praticamente abolida do meio acadêmico (SACCO, 2001, p. 33). Sem que fossem dadas maiores justificativas e com pouquidade de elucidação, artigos e manuais passaram, quando muito, apenas a reproduzi-la exemplificadamente e a tomar partido no sentido de assumir uma das fórmulas vistas acima (CONSTANTINESCO, 1998, pp. 279-280).

Insertos nesta conjuntura, com os representantes do clássico direito constitucional comparado, isso não se mostrou diferente. Afinal, levando-se em conta o desenvolvimento acadêmico tardio da referida disciplina em relação ao que fora produzido no domínio do direito privado, tais autores acabaram por não participar ativamente da querela em comento, posto que seus trabalhos se deram apenas quando tal disputa já se encontrava em declive (MARQUES,

\footnotetext{
${ }^{4}$ Em geral, os autores que postulam tal compreensão, apenas afirmam sem, contudo, apresentar suas razões para tanto. É o caso, por exemplo, do trabalho organizado por Henri Capitant (1930, p. 208), no qual se identifica o Direito comparado como "[...] um ramo da ciência jurídica que tem como objeto a aproximação sistemática das instituições jurídicas dos diversos países [...]".

${ }^{5}$ Sem dúvidas, neste particular, os que mais se destacam são os juristas Raymond Saleilles e Édouard Lambert. Contudo, podem também ser destacados autores como Georges Sauser-Hall e Henri Levy-Ullmann.

${ }^{6} \mathrm{O}$ maior defensor desta tese é o professor americano John Henry Wigmore. Entretanto, como identifica LeontinConstantinesco (1998, p. 313), seu argumento é falho na medida em que apenas descreve o processo metodológico e determina alguns dos principais escopos deste campo, sem com isso definir o que na verdade seria a ciência do Direito comparado para ele.

${ }^{7}$ Advogada principalmente por BorislavBlagojevic (1953, p. 656), o Direito comparado para o mesmo somente evoluiria para o patamar de uma ciência autônoma se e quando o estudo comparatista fosse sistemático, ocorre que como salienta Constantinesco (1998, p. 315), a tese torna-se estéril e de pouco interesse, já que o próprio expoente desta corrente não identifica o que caracterizaria essa sistematicidade.

${ }^{8}$ São partidários desta concepção principalmente os autores alemães Ernst Rabel e Erich Rothacker.

${ }^{9}$ Posição adotada tanto por Feuerbach quanto por Heinz Kohler.
}

Revista de Direito Brasileira | São Paulo, SP | v. 19 | n. 8 | p. 184 - 207 |Jan./Abr. 2018 
2014). Neste sentido, em alguns casos, como por exemplo nas obras de BiscarettidiRuffia, ${ }^{10}$ e Giuseppe de Vergottini, os publicistas sem maiores e aprofundadas considerações, apenas manifestavam diretamente sua posição. Já em outros, e de forma diversa, como se pode ver em uma obra cuja autoria pertence a José Afonso da Silva, ${ }^{11}$ tanto era costume ser destinado um item ou um capítulo para apresentar a contenda, quanto se aproveitava da ocasião para se fazer um resgate abreviado da mesma, assumindo o autor na sequência a sua posição. A partir daí, preenchida tal etapa de caráter propedêutico, os autores, via de regra, sentiam-se então aptos a se dedicarem aos assuntos que como será exposto no próximo ponto, desafiavam o direito comparado no âmbito constitucional.

\section{O DIREITO CONSTITUCIONAL COMPARADO TRADICIONAL E SEUS PRINCIPAIS IMPASSES: UMA MIRADA ELUCIDATIVA A PARTIR DA DOUTRINA}

Consoante os apontamentos engendrados por Giuseppe de Vergottini (2004, p. 02), ${ }^{12}$ pode-se assegurar a existência de três problemas fundamentais, que somados ao intrincado questionamento visto no ponto antecedente, tanto atemorizaram os estudiosos do cotejamento lato, quanto com o escoar do tempo e a particularização cada vez maior das pesquisas em domínios jurídicos delimitados, passaram a ser também encontráveis nas obras dos teóricos adeptos da vertente clássica do direito constitucional comparado. Em resumo, os mesmos que serão melhor estudados nas linhas subsequentes podem ser apresentados através dos seguintes questionamentos: para que se compara, ou o problema da finalidade; o que se compara, também conhecido como o problema do objeto; e por último, como comparar, ou o impasse sobre o método.

Antes, porém, de nos aprofundarmos em cada um destes temas, vale aqui uma breve consideração sobre o que entendem por Direito constitucional comparado os autores que compõem a sua tendência tradicional. Em tal âmbito, apesar de existir uma pluralidade de conceitos elaborados e difundidos, como muito bem aponta José Afonso da Silva (2006, p. 348), todos possuem um mesmo núcleo em comum. Quer dizer, percebe-se a existência de um certo acordo informal entre os estudiosos a respeito de uma mesma visão de mundo, segundo a qual, nesta alçada, comparar traduz-se necessariamente em confrontar particularidades institucionais e normativas constantes dos sistemas constitucionais de mais de um Estado. ${ }^{13}$ Nesta senda, partese, portanto, da premissa de que afim de colocar em evidência tanto as diferenças quanto as similitudes entre soluções jurídicas diversas, para extrair daí conclusões e representações ótimas

\footnotetext{
10 Segundo o jurista italiano (RUFFIA, 1974, p. 03): “[...] para esclarecer o conceito de ciência do direito constitucional comparado, pode-se afirmar preliminarmente que o mesmo se põe ao lado do direito constitucional particular \{que se baseia em um único ordenamento estatal\} e o direito constitucional geral \{capítulo específico da teoria geral do direito destinado a compreender em seus esquemas dogmáticos, uma série vastíssima de institutos, a partir do maior número de direitos positivos \} - como uma das ciências jurídicas que se relacionam com o estudo aprofundado dos estados constitucionais [...]".

${ }^{11} \mathrm{Na}$ linha do que fora feito aqui, todavia, de forma mais simplista, José Afonso da Silva (2006, pp. 266-267) em texto intitulado "Direito constitucional comparado e processo de reforma do Estado", faz um apanhado das três posições fundamentais sobre a natureza da comparação jurídica. Na ocasião, o autor, assim como o fizemos, chama a atenção tanto para os estudiosos que entendem que tal disputa é estéril, quanto para os autores que tomam o direito comparado enquanto um método ou uma disciplina científica autônoma.

${ }^{12}$ No mesmo sentido, aliás, pode-se citar também Paolo BiscarettidiRuffia (1974, p. 03).

${ }^{13}$ Conforme salienta Giuseppe de Vergottini (2004, p. 27) “[...] A comparação pode se referir a ordenamentos contemplados em seu conjunto, macrocomparação, ou a setores ou institutos concretos, microcomparação. A comparação de dois ordenamentos, por exemplo, o italiano e o francês, é certamente possível, porém, em razão do caráter extremamente amplo de seus termos, a mesma pode ser problemática, concedendo resultados excessivamente genéricos. Mas factível é a comparação de setores dos respectivos ordenamentos, ou melhor, a que considerando os ordenamentos francês e italiano como dois sistemas normativos, se efetua entre dois de seus respectivos subsistemas, por exemplo, o direito parlamentar francês e o italiano [...]".
}

Revista de Direito Brasileira | São Paulo, SP | v. 19 | n. 8 | p. 184 - 207 |Jan./Abr. 2018 
de uma determinada estrutura, ${ }^{14}$ faz-se imprescindível o acareamento do modo como as leis básicas no todo ou em parte, assim como as instituições que delas derivam, são trabalhadas em um dado ambiente nos seus mais variados matizes (RUFFIA, 1974, pp. 03-04).

Ocorre que, conforme salienta García-Pelayo (1984, p. 20), para além do que ao contrário possa à primeira vista parecer, as singularidades perquiridas e no mais das vezes alcançadas pelas pesquisas empreendidas neste particular, não necessariamente podem oudevem se basear apenas e tão somente no confrontamento realizado entre preceitos positivos vigentes, isto é, valendo-se do chamado critério espacial. Há, por conseguinte, a possibilidade de que o mesmo se dê igualmente através do critério temporal, ${ }^{15}$ quer dizer, de molde a considerar em grau equânime, também os cânones provenientes de épocas distintas, restringido-se, todavia, neste caso, ao estudo único e exclusivo de um mesmo Estado. Isso porque, como questões "[...] idênticas ou similares se põem em múltiplos países ou se puseram no passado no mesmo país, faz-se mister conhecer não unicamente como o Direito posto as considera aqui e agora, mas também como são consideradas noutros sistemas, ou indo mais além, como foram noutras épocas no mesmo país [...]" (MIRANDA, 1990, p. 25). ${ }^{16}$ E neste entrecho, representa bem o referido cenário, a demarcação proposta por Canotilho (2003, p. 156), de acordo com o quem, "[...] por ciência do Direito constitucional comparado entende-se a ciência que estuda, descreve e explica vários sistemas constitucionais positivos, mas não necessariamente vigentes, tentando captar as suas dimensões fundamentais e os seus traços unificadores[...]”.

Ora, de posse de tais informações, abre-se na sequência das mesmas a oportunidade de, enfim, nos imiscuirmos no primeiro dos três problemas à que se chamou à atenção no começo deste ponto, qual seja, o da finalidade. $\mathrm{Na}$ esteira do que já larga e amplamente havia sido rematado no corpo das perquirições desempenhadas na esfera privada e mercantil, os estudiosos tradicionais do direito constitucional comparado, valendo-se em grande medida do esforço daqueles, mas guardadas, entretanto, as devidas proporções, chegaram à conclusão da existência de duas funções para a referida disciplina: uma de gradação primária e outra de escala secundária (VERGOTTINI, 2004, p. 03). No que tange a primeira delas, com a qualpraticamente consentem todos os autores, segundo Giuseppe de Vergottini (2004, p. 04), esta teria como âmago a cognoscibilidade, quer dizer,

"[...] através do estudo comparado de ordenamentos ou de institutos de distintos ordenamentos surgem elementos de conhecimento indispensáveis para a ciência do direito constitucional. Um exemplo clássico se constitui no estudo comparado do qual se extrai aquele conhecimento que nos permite elaborar categorias classificatórias para enquadrar e analisar as diversas experiências constitucionais. Os conceitos de forma de Estado e sistemas de Governo procedem justamente de intentos de clarificação realizados pelos estudiosos dos ordenamentos políticos e jurídicos através de investigações comparadas das experiências institucionais do passado e do presente. Deste modo, a comparação pode, portanto, oferecer uma ajuda válida na construção dos conceitos com que

\footnotetext{
${ }^{14}$ Vale destacar que “[...] do ponto de vista metodológico, a diferença entre o simples estudo de um ordenamento estrangeiro e sua consideração de efeitos comparativos consiste que no primeiro há um caráter meramente descritivo, enquanto que no segundo, supõe-se além do conhecimento de mais de um ordenamento, um exame conjunto e uma operação lógica de contraste donde se extraem conclusões [...]" (VERGOTTINI, 2004, p. 26).

${ }^{15}$ Esta distinção entre critério espacial e temporal pode também ser desenhada através das expressões comparação horizontal para a primeira e comparação vertical para a segunda (DANTAS, 2006, p. 114).

16 Vale, porém, a menção de que embora tal divisão seja majoritária em sede doutrinária, a mesma não é unânime.Isso porque, como aponta Ivo Dantas (2006, p. 115), falar em Direito comparado significa reconhecer a existência de dois ou mais sistemas jurídicos vigentes que serão confrontados, e dos quais, preferencialmente, um deles é o nacional. Neste sentido, só haveria, portanto, espaço para a ocorrência do critério espacial, visto que fazer a evolução de um instituto, por exemplo, do Federalismo, em suas diversas fases dentro do mesmo sistema jurídico, seria, na verdade, fazer História do Direito.
} 
se formam as categorizações, com base nos quais, aliás, se desenvolve tanto o estudo do direito constitucional lato sensu, como, em especial, de sua vertente comparada $[\ldots . . . "$

Já por seu turno, no que se refere à finalidade secundária, a mesma poderia ser sintetizada do seguinte modo: os resultados obtidos através da comparação podem ser utilizados também para objetivos outros além do mero conhecimento. ${ }^{17}$ Acontece que neste extrato, pouco ou quase nenhum acordo há sobre quais seriam os demais alvos. Cada autor, no geral, apresenta a sua lista e a ordena de acordo com seus próprios critérios (OBIORA, 1998, p. 921). Assim é que, por exemplo, para Paolo BiscarettidiRuffia (1974, pp. 05-07), os escopos se reduziriam em três: realizar uma melhor avaliação do ordenamento nacional, figurar como material de consulta a ser utilizado pela política legislativa, e é claro, alcançar a unificação jurídica. Em outra borda, para Giuseppe de Vergottini (2004, pp. 07-23), os fins na verdade se agrupariam em torno de cinco proposições, três semelhantes às elencadas por diRuffia, e duas distintas. No que toca as congêneres, estas seriam, primeiro, auxiliar na preparação de textos normativos, segundo, compreender com mais acerto os institutos internos, e por último, eliminar as barreiras que impedem a unificação jurídica dos Estados. Já as díspares, de outra monta, seriam tanto comprovar ou refutar as investigações realizadas por métodos diversos, quanto auxiliar na tarefa interpretativa.

Sucede que, apesar desta inconveniente divergência, a mesma, no entanto, não nos impede de perceber, como para os teóricos da vertente clássica do direito constitucional comparado, os fins deste praticamente não guardavam qualquer referência com sua possível aplicação pelos tribunais constitucionais. ${ }^{18}$ A única exceção, talvez, de que se tenha conhecimento, e até por que a obra da qual ela advém se situa em um período de transição, ${ }^{19}$ fica por conta da ressalva veiculada por Giuseppe de Vergottini. ${ }^{20}$ Desconsiderando-se, porém, o manifesto, mas sutil reconhecimento do hoje professor emérito da Universidade de Bologna, pouquíssima atenção acabou por caminhar nesta direção. Afinal, diante de uma conjuntura onde o judiciário carecia de importância frente ao legislativo, às possibilidades, como consequência retilínea, revelavam-se extremamente limitadas aos juízes.

Dando sequência, considerando-se agora a questão a respeito do objeto ${ }^{21}$ da comparação, aqui, segundo opinião generalizada dos doutrinadores clássicos, podem ser incluídos tanto o

\footnotetext{
${ }^{17}$ No mesmo sentido, caminha a orientação de Roberto Scarciglia (2011, p. 70), segundo o qual "[...] se pode afirmar que a função primária da comparação, tanto no Direito privado, como no Direito público, é a do conhecimento dos ordenamentos estrangeiros, todavia, é precisamente mediante a aquisição de novos elementos cognitivos o que permite a perseguição de finalidades ulteriores tanto teóricas quanto práticas. E isto vale tanto para o Direito, e seus ramos específicos, como para outras ciências. Desta forma, a função secundária, é então, a utilização dos resultados obtidos mediante a análise comparada $[\ldots .$. ".

${ }^{18}$ Como identificam Carlos de Almeida e Jorge Carvalho (2013, p. 21), com diferentes amplitudes, quase todos os comparatistas consideravam também a organização judiciária como usuária do material contrastado, porém, muito poucos, talvez até mesmo porque o direito constitucional comparado ainda era muito incipiente, aditavam neste âmbito as jurisdições constitucionais.

${ }^{19}$ Diz-se período de transição, uma vez que a mesma fora publicada já na década de 80, quando alterações políticas que iriam influenciar o desenrolar do Direito comparado já começavam a serem sentidas.

${ }^{20}$ A referência aqui é ao trabalho "Dirittocostituzionalecomparatto". Aí, de acordo com o autor (VERGOTTINI, 2004, p. 12), "[...] se percebe como a integração entre ordenamentos conduz inevitavelmente ao recurso da comparação na interpretação das normas sobre os direitos, realizada pelos tribunais constitucionais [...]".

${ }^{21}$ Interessante notar que de acordo com uma parte da Doutrina, o objeto da comparação pode também ser nomeado de "formante", é o que assume, por exemplo, em um aspecto mais geral, Rodolfo Sacco (1991, p. 343), e no plano específico do Direito constitucional, local onde, aliás, isso pouco se vê, Roberto Scarciglia (2011, p. 116). Nesta esfera, formariam o grupo dos chamados "formantes principais", tanto a Lei, como também a Doutrina e a Jurisprudência de um país, sendo esta última no caso, visualizada com muito mais frequência e abertura tanto na seara privatista, quanto no contexto do Common Law. Já quanto ao demais, isto é, no que tange aos outros objetos que não se encaixam em nenhum dos "formantes" tidos como principais, estes receberiam o nome de "criptotipos".
} 
Direito positivo, quanto por via reflexa, as instituições que dele provêm (VERGOTTINI, 2004, p. 24). Todavia, em termos práticos, é possível afirmar aqui, que os textos das inúmeras cartas magnas encontráveis ao redor do globo, tratam-se, na verdade, do material ordinário para a análise comparativista. Isso por que, nesta alçada, um primeiro adendo já deve ser feito, afinal, como muito bem aponta Paolo BiscarettidiRuffia (1974, p. 09), os que neste bojo pretendem se aventurar, devem estar sempre atentos também ao fato de que dependendo do caso, poderão ocasionalmente se enveredar por destinos outros, nos quais o que prevalece são as regras consuetudinárias. Tais exceções, como no caso, por exemplo, do sistema jurídico britânico, regulado por um Direito comum, em geral não escrito, ao contrário do que se poderia pensar, de maneira nenhuma teriam o condão de desnaturalizar o cotejamento em âmbito constitucional, isso porque, nestes casos, de modo a suprir à regra geral, a pesquisa seria plenamente possível de ser realizada, desde que, para tanto, se levassem em conta às chamadas convenções constitucionais. $^{22}$

Ocorre que para além desta excepcionalidade, uma outra ressalva precisa igualmente ser feita. Afinal, embora a abordagem positivista pura e simples tenha, por alguns anos, prevalecido entre os trabalhos realizados na esfera do direito constitucional comparado, com o desenrolar do tempo, a mesma acabou se mostrando insuficiente para atingir robusta e confiavelmente os infindáveis propósitos à que, como visto, se pretendia alcançar com o cotejamento (MIRANDA, 1970, p. 41). Diante de tal contexto, não demorou muito até que os que se preocupavam com a construção e o desenvolvimento do campo em tela chegassem à conclusão da importância de se examinar o Direito posto, sem, porém, dissociá-lo da realidade social. ${ }^{23}$ Isso por que, “[...] a divergência, potencial ou efetivamente produzida, entre os textos normativos e o Direito que se aplica na prática, reveste-se de particular importância, sobretudo no campo constitucional, já que nele a influência da política condiciona evidentemente a aplicação da norma positivada [...]" (VERGOTTINI, 2004, p. 28). ${ }^{24}$

Neste âmbito, levando-se em conta então que os textos normativos somente criam algumas condições de desenvolvimento, de transformação e de realização política, e mais do que isso, não são os fatores determinantes de um dado regime constitucional (MIRKINEGUETZEVICH, 1951, p. 195), para que fosse impressa confiabilidade às pesquisas comparatistas, não houve outra alternativa senão a defesa de que as mesmas migrassem para além da simples análise formal. Consequentemente, em associação a esta, e de modo a complementá-la passou a gozar do mesmo grau de importância entre os autores clássicos, a obtenção tanto de um conhecimento geral da história política de um Estado qualquer, quanto também de seu sistema de fontes e a aplicação da normativa constitucional no plano fático (VERGOTTINI, 2004, pp. 25). Tal mudança de paradigma, aliás, acabará inclusive por influenciar o próprio procedimento comparativo, vez que, apreender o cenário no qual se encontra o Direito será alçado ao patamar de estágio deste.

\footnotetext{
22 As convenções constitucionais são acordos de procedimentos informais, não codificados, e seguidos pelas instituições de um determinado Estado. São encontráveis, sobretudo, nos países onde se dá o chamado sistema de Westminster, leia-se, Reino Unido e algumas de suas antigas colônias.

${ }^{23}$ Tal pressuposto, Jorge Miranda (1970, p. 42) dará o nome de "necessidade de localização", isto é, “[...] a necessidade de raciocinar dentro dos quadros conceituais e técnicos do direito constitucional donde se isolam os institutos, objeto da comparação, e a necessidade de contemplar as condições de aplicação das normas no ambiente e no estágio social em causa [...]".

${ }^{24}$ Neste diapasão, Giuseppe de Vergottini (2004, p. 29), inclusive, vai além, chegando até mesmo a afirmar que seria “[...] absolutamente impensável limitar a comparação exclusivamente ao direito formalizado, isto é, escrito e codificado. Ao assim se proceder, a comparação resultaria parcial, distante da realidade social e jurídica e, portanto, sem valor. Afinal, o direito constitucional, para além de ser o direito da organização social e da liberdade, e em quanto tal, em princípio codificado, normalmente é também o direito do fato político, na medida em que consiste em um conjunto de normas que tende a regular o desenvolvimento da ação política [...]".
}

Revista de Direito Brasileira | São Paulo, SP | v. 19 | n. 8 | p. 184 - 207 |Jan./Abr. 2018 
Ora, nesta senda, questão interessante e que, inclusive, atravessou todo o desenvolvimento do clássico Direito constitucional comparado, diz respeito a saber se existem vários ou apenas um método neste meio. Discussão complexa, aplicada mais às investigações acadêmicas, e que iguamente por exceder o propósito destas linhas, vale apenas destacar que reconhecida à pluralidade dos métodos, ${ }^{25}$ a escolha de um sempre corresponderá à valoração pessoal do estudioso frente aos objetivos que o mesmo pretende alcançar (SCARCIGLIA, 2011, p. 87). Feita, porém, esta opção pelo pesquisador, que, aliás, pode ser por ele adaptada, ${ }^{26}$ o que no geral se pede do mesmo, é que o estudo comparativo percorra três fases procedimentais, ou momentos lógicos, expressos em regra na seguinte ordem: conhecimento, compreensão e comparação stricto sensu. ${ }^{27}$ Tais etapas, de acordo com José Afonso da Silva (2006, p. 275), por serem complementares, obrigam necessariamente o pesquisador a seguir de forma rigorosa a disposição que se encontra indicada. ${ }^{28}$ Isso por que, conforme alude o professor emérito da Universidade de São Paulo,

"[...] o conhecimento das partículas jurídicas elementares que formam o termo a comparar não é senão a preparação obrigatória pela qual o comparatista consegue, na fase posterior, a compreensão dos termos a comparar no quadro de seus ordenamentos constitucionais, e essa compreensão, por seu lado, é condição indispensável à comparação propriamente dita. Quer dizer, deve-se conhecer para compreender e deve-se compreender para poder comparar [...]".

No que toca ao primeiro dos três estágios, qual seja, o do conhecimento, este tem por finalidade ser um momento no qual o estudioso buscará compilar informações à respeito do objeto em apreciação (SCARCIGLIA, 2011, p. 93). Para tanto, exige-se do mesmo a observância de dois princípios, um segundo o qual o direito constitucional estrangeiro deve ser examinado, dentro do seu quadro, e operando-se com seus conceitos, sua lógica e seus métodos de interpretação, e outro, de acordo com o qual, do investigador se espera que este aja como jurista do ordenamento em análise, recorrendo-se, portanto, das mesmas fontes, as atribuindo o mesmo valor, e interpretando-as da mesma maneira (SILVA, 2006, p. 276). Quer dizer, em outros termos, tais princípios podem ser sumarizados em cinco passos dispostos da seguinte forma: 1) o objeto deve ser estudado tal e como aparece na realidade; 2) o exame deve ser feito considerando

\footnotetext{
${ }^{25}$ No geral, quer dizer, ainda que escape um ou outro de menor importância entre as obras de Direito comparado, reconhece-se a existência de ao menos três métodos, diferenciados quanto ao cerne. No que se refere ao primeiro deles, o da aproximação funcional, "[...] diz-se, não é abstrato e jurídico, mas concreto, funcional e social. Através dele, comparáveis são os institutos jurídicos que, em diversos sistemas e com soluções eventualmente diversas, dão resposta jurídica a necessidades semelhantes, e resolvem o mesmo problema da vida, isto é, o mesmo problema social, político, econômico ou criminológico [...]" (ALMEIDA \& CARVALHO, 2013, p. 23). Já o segundo, que se subdivide em dois, o método problemático, e o método casuístico, a escolha de um não necessariamente exclui o uso do outro, podendo ambos serem resumidos da seguinte forma, enquanto o ProblemMethod centra seu interesse no estudo comparado de um problema concreto, o Case Method se caracteriza pelo estudo e exame de casos judiciais (SCARCIGLIA, 2011, p. 88). Quanto ao terceiro, também conhecido como método factual, a ideia fundamental consiste em "[...] apurar a existência de funções ou subfunções sociais comuns em diferentes sistemas jurídicos, a partir de segmentos da vida ou pequenas unidades de discussão, tal como resultam de questionários elaborados com base em situações de fato. A comparação far-se-á com base nas respostas obtidas, que indicam o modo como cada sistema jurídico reage às várias situações de fato constantes do questionário [...]" (ALMEIDA \& CARVALHO, 2013, p. 23).

${ }^{26}$ Isso porque como há distinção de foco entre os métodos, ao se aplicar um deles, pode ser que eventualmente não seja necessário passar por todas as fases indicadas.

${ }^{27}$ Exatamente por isso, este iter é também muito conhecido como a regra dos três " $\mathrm{C}$ ".

${ }^{28}$ Uma observação, porém, deve ser feita, afinal, como sublinham Carlos de Almeida e Jorge Carvalho, (2013, p. 27) "[...] cada uma das fases se relaciona com as outras em termos dialéticos, sendo por vezes útil ou necessário retornar a uma fase anterior para rever, reformular e alterar resultados provisórios, em consequência da investigação nas fases seguintes $[\ldots] "$.
} 
suas fontes originais e autênticas; 3) há de se estudá-lo a partir da complexidade e totalidade das fontes de Direito; 4) não se pode permitir que se desrespeite a hierarquia que há entre estas; e por último, 5) o termo deve ser interpretado de acordo com o método hermêneutico empregado no ordenamento constitucional em foco (SCARCIGLIA, 2011, p. 94).

Após transcorridos estes estágios, na sequência, alcança-se a etapa da compreensão. Nela, parte-se do pressuposto de que a visão global da ordem jurídica e a integração de suas instituições não se compadece com uma atitude exclusivamente sincrônica e limitada aos dados do sistema jurídico. Nesta direção, a consideração, portanto, de elementos histórico-juridicos, além de elementos meta-jurídicos (de outros sistemas sociais), mostra-se indispensável para o sucesso desta fase (ALMEIDA \& CARVALHO, 2013, p. 29). Quer dizer, enquanto na primeira parte do percurso, o objeto da comparação é apreciado de forma isolada, isto é, observado apenas e tão somente nos seus pormenores técnicos, na segunda, o estudioso precisa relacioná-lo ao meio político, social e econômico (SILVA, 2006, pp. 276-277). Assim, o que se propõe aqui, é apreender o papel que um determinado termo desempenha na ordem jurídica a que pertence, porém, para que isso seja feito, é necessário ir adiante, quer dizer, há de se compreendê-lo também dentro da atmosfera imaterial na qual este se encontra imerso.

Dando prosseguimento, após vencer as duas primeiras etapas, o material a comparar finalmente encontra-se apto a converter-se em um instrumental para a terceira e última fase do processo metodológico. Neste plano, o investigador necessariamente deverá assumir três posturas, sendo a primeira, identificar e destacar as relações de semelhança e de discrepância que existem entre os ordenamentos acareados; a segunda, englobar na síntese comparativa as ligações que eventualmente surgem nos mais diversos planos durante o desenvolvimento do estudo; e, por fim, evitar qualquer conclusão antes de se ter esmiuçado toda a realidade jurídica das ordens a que o termo pertence (SILVA, 2006, p. 277). Observados e cumpridos tais trâmites, a partir daí, os resultados obtidos estarão, agora sim, livres para serem utilizados cada qual de forma distinta, dependendo dos intentos, que como se sabe, inspiram e movem o pesquisador.

Ora, visto isso, e uma vez concluída a ilustração dos temas principais que nortearam as discussões em torno do direito constitucional comparado durante o seu ciclo clássico, abre-se enfim a oportunidade de, como destacado previamente, nos imiscuirmos nos assuntos nevrálgicos pelos quais tem avançado sua tendência contemporânea. Neste contorno, a proposta do ponto seguinte nada mais é do que promover uma reflexão à respeito de temas que dialogam diretamente com o renovado ímpeto que tem caracterizado boa parte dos trabalhos atuais, qual seja, a utilização do referencial estrangeiro pelas supremas cortes. Assim, por óbvio, novas indagações como, em qual ocasião, por qual motivo, e de que forma, juízes ou tribunais, no plano constitucional, se socorrem ou deveriam se socorrer do material alienígena, são impasses que não poderão ser neglicenciados.

\section{O DIREITO CONSTITUCIONAL COMPARADO HODIERNO: INQUIETAÇÕES DE UM NOVO RUMO}

Diferentemente dos autores clássicos, que na sua grande maioria dedicavam-se em ao menos uma das seções de seus trabalhos, a expor de forma direta o conceito que tinham sobre o direito constitucional comparado, entre os estudiosos de hoje não se percebe a mesma preocupação. No entanto, à luz deste cenário, embora em um primeiro momento possa se concluir equivocadamente ser inviável demonstrar o contraste que existe entre uma concepção e outra, o que se busca evidenciar aqui é justamente o contrário. Afinal, basta uma leitura um pouco mais atenta, para perceber que mesmo de forma despretensiosa, há também nos dias atuais um cuidado por parte dos comparatistas no sentido de frisar o que os particulariza. É o que, inclusive, se mostra cristalino, no que muito precisamente pontua LorraineWeinrib. Segundo a professora da Universidade de Toronto (WEINRIB, 2002, p. 03-04), levando-se em conta os 
empreendimentos realizados no passado, a confrontação em âmbito constitucional na atualidade, tem se enveredado por um universo bem mais amplo. Isso porque, se antes o uso do referencial alienígena ficava restrito praticamente a pesquisaacadêmica e aos processos de edição de novas cartas políticas, ${ }^{29}$ nos dias correntes, a prática de se referir a experiências estrangeiras passou a também ser encontrada de modo regular nos domínios da jurisdição constitucional, seja ela vinculada a tradição jurídica do common law, seja, como reconhece Lucio Pegoraro (2008, pp. 406-407), pertencente à família romano-germânica.

Tais tribunais, através de um processo de justificação discursiva (CHOUDHRY, 2006, p. 22), ${ }^{30}$ vêm se apropriando do material comparado assim como se faz com os conselhos de alguém mais experiente, para tomar decisões, sobretudo em casos que envolvam questões de natureza complexa $^{31}$ (BARAK, 2005, p. 196). Quer dizer, quando uma corte se encontra diante de dissensos nos quais os materiais jurídico-positivos não conseguem dar conta (CHOUDHRY, 2006, p. 04), o elemento forasteiro durante o progresso da tarefa interpretativa, acaba funcionando, por consequência, como um importante argumento de persuasão (SMITS, 2006, p. 483). ${ }^{32}$ Ocorre que, como salienta TaaviAnnus (2004, p. 319), em razão do uso ou não da experiência estrangeira ser sempre uma opção estratégica, o que, como resultado, permite aos juízes, por exemplo, omitirem aquelas referências que não suportam suas opiniões. O peso, a ser dado a cada uma delas, pode não necessariamente ser o mesmo. Neste sentido, para o autor, é possível que haja uma gradação quanto ao emprego do aparato externo, que no caso, poderá ser sempre soft ou hard. ${ }^{33}$

O modo soft é o que simplesmente discute as práticas alienígenas sem, porém, conferir uma importância considerável as mesmas para a decisão final, isto é, trata-se apenas de uma fonte de inspiração (ANNUS, 2004, p. 314), que segundo David Fontana (2001, p. 552), será sempre estabelecida obter dicta. Em tais termos, uma corte pode então utilizar a referência estrangeira simplesmente para pontuar como uma discussão está se encaminhando em outros lugares. ${ }^{34}$ Ouem outras ocasiões, pode achar por bem se valer do direito constitucional comparado, apontando para a adoção de uma regra particular ou de um princípio, ou ainda reconhecendo algum fato relevante, sem com isso, porém, fazer com que tal registro conste como parte da decisão final tomada.

De outra forma, no que se refere ao uso hard, ${ }^{35}$ neste, as cortes conferem as referências um grau um pouco mais acentuado de relevância, podendo as mesmas, ademais, serem uteis para dois propósitos: ajudar na ponderação de diferentes valores constitucionais, ${ }^{36}$ ou ainda, funcionar

\footnotetext{
${ }^{29}$ Isso não quer dizer que tal prática tenha encontrado seu fim. Só que somada a ela, chama a atenção também a atividade do uso do direito constitucional comparado pelas supremas cortes (CHOUDHRY, 2006, p. 13).

${ }^{30}$ Por este tipo de processo, leia-se, o ato de juízes se utilizarem argumentativamente das experiências estrangeiras, discutindo-as, analisando-as, distinguindo-as, ou ainda as tomando emprestado, de modo a justificarem uma posição por eles adotada (HARDING, 2003, p. 425).

${ }^{31}$ Também conhecidos como hard cases, o que segundo David Fontana (2001, p. 558) significa "[...] os casos nos quais um novo problema é apresentado a corte, e onde ainda que as fontes apontem em uma determinada direção, não houve nenhuma experiência prática de como uma decisão em uma direção ou em outra vai funcionar [...]".

${ }^{32}$ Aqui é importante destacar, à luz do que pontua Christopher McCrudden (2000, p. 502), a diferença que existe entre argumento de autoridade e argumento persuasivo. Enquanto em relação ao primeiro, o juiz deve aplicar e seguir, sendo por ele, até mesmo, limitado, o argumento persuasivo por outro lado, não o vincula.

${ }_{33}$ Cabe aqui salientar, que como registra CherylSaunders (2006, pp. 49-50), esta é uma das muitas tentativas de categorizar o peso do direito estrangeiro no plano da jurisdição constitucional. Porém, como nenhuma delas atende plenamente a diversidade das formas em que os tribunais se referem às outras experiências, optou-se por trazer à baila a de TaaviAnnus, por se tratar da de mais fácil compreensão.

${ }^{34}$ Um exemplo aqui é o caso Washington v. Glucksberg (521 U.S. 702 1997) onde o ChiefJustice Rehnquist fez menção ao direito constitucional comparado para demonstrar como a matériaestava sendo discutida no mundo.

${ }^{35}$ Também chamado de uso normativo, isto é, o fato de uma referência estrangeira ser utilizada ao menos como um dos importantes fatores que favorecem o alcance de um determinado resultado (SMITS, 2006, p. 488).

${ }^{36}$ De acordo com Jan Smits (2006, p. 489) o melhor exemplo neste âmbito são os casos onde há um certo consenso internacional ou uma solução estrangeira muito boa sobre determinada matéria. Neles, a referência é tida como um Revista de Direito Brasileira | São Paulo, SP | v. 19 | n. 8 | p. 184 - 207 |Jan./Abr. 2018
} 
como instrumento de previsão das possíveis consequências provenientes de uma decisão específica (ANNUS, 2004, p. 314). ${ }^{37}$ No primeiro caso, o tribunal busca se beneficiar da sabedoria adquirida por outro país, razão pela qual este tipo de abordagem é mais apropriado tanto para situações onde é a primeira vez que se trata de um dado problema, quanto para momentos onde falta clareza às fontes. Já no segundo caso, a ideia é fazer uma projeção de aceitabilidade ou avaliar a racionalidade de uma eventual decisão, para ver se um dos possíveis fins é ou não atraente (FONTANA, 2001, pp. 552-556).

Acontece, porém, que como intimamente relacionados a essa atribuição diferente de grau, encontram-se tanto um sem número de motivos (JACKSON, 1999, p. 591), como também estes mesmos se apresentam de forma encoberta. Em atendimento ao que se propôs discutir neste ponto, listar tais fatores torna-se uma tarefa de dimensões hercúleas, que, inclusive, vale a menção, não conseguirá retratar a realidade na sua completude, já que esta é sempre fugaz e, portanto, não comporta categorizações. Diante disto, o que se percebe, é sempre uma tentativa por parte dos autores, de oferecer quando se encontram desenvolvendo pesquisas neste âmbito, um panorama o mais fiel possível das inúmeras razões que podem levar um tribunal a se socorrer de referências externas (DAMMANN, 2002, p. 522). Contudo, como na maior parte dos casos não há um diálogo entre os mesmos, no fim, trabalhos que se complementam ou que até mesmo se sobrepõe são encontrados frequentemente. Assim sendo, de modo a não comprometer o desenvolvimento do presente artigo, mas também sem deixar de oferecer um quadro satisfatório dos prováveis fundamentos que podem influenciar os tribunais neste particular, optou-se aqui, por se apresentar na sequência, um rol ilustrativo, mas ao mesmo tempo abrangente de tais razões.

E neste âmbito, sem dúvidas, uma primeira listagem que não pode deixar de ser citada, é a que é apresentada por TaaviAnnus. De acordo com o autor (2004, p. 343), a prática de se valer de experiências estrangeiras é vista por boa parte dos estudiosos como sendo sempre tributária da motivação que pode orientar ou os juízes ou as cortes em geral. Quer dizer, as abordagens neste âmbito partem da compreensão de que a escolha por usar ou não este aparato pode ser fruto às vezes de uma opção pessoal e outras de uma opção institucional. Quando se trata da perspectiva individual, TaaviAnnus (2004, p. 36) identifica dois fundamentos potenciais. O primeiro e mais frequente, seria atitudinal, isto é, em alguns casos, os juízes usariam o direito comparado sempre que este material apoiasse suas teses, não se preocupando, portanto, com qualquer tipo de questão lógica ou mesmo de legitimidade. Já, quanto ao segundo, este levaria em consideração o fato de que os juízes diante do caso concreto optariam por empregar a referência exterior a partir de uma decisão racional, e exatamente por isso, não se socorreriam deste arcabouço com tanta facilidade, uma vez que estariam sempre preocupados em saber como um discurso com tal argumento seria percebido pelos colegas de judicatura, bem como pelas demais instituições. ${ }^{38}$

No tocante a percepção institucional, entretanto, vale destacar, que se estrutura sobre o pressuposto de que uma corte é, na verdade, um ator unitário, e por assim ser, pode eventualmente se valer do direito contrastado com o objetivo de persuadir os demais poderes instituídos a não modificarem a posição por ela tomada (ANNUS, 2004, p. 343). ${ }^{39}$ Quer dizer,

argumento que em conjunto com outros será ponderado pelo tribunal, tornando-se, por consequência, codecisivo para o desfecho interpretativo.

${ }^{37}$ Quer dizer, para Annus (2004, p. 337), as experiências estrangeiras seriam como laboratórios, que permitem tanto evitar erros cometidos em outros lugares, quanto prever os eventuais acertos.

${ }^{38}$ É o que deixa claro TaaviAnnus, segundo o autor “[...] o modelo atitudinal sugere que os juízes votam suas sinceras preferências, enquanto que no modelo racional, os magistrados são constrangidos por fatores internos e externos; internamente eles precisam acomodar e barganhar com o objetivo de ganhar o apoio de outros justices, externamente eles precisam considerar a interação entre diferentes poderes [...]".

${ }^{39}$ Isto por que, como sublinha William Eskridge (1991, p. 644), o tribunal constitucional é um dos atores do jogo “corte/congresso/presidente". Nele "[...] cada jogador opera com informações completas sobre as preferências dos outros jogadores, e assim, pode antecipar perfeitamente o futuro do curso do jogo. Além disso, cada jogador ao fazer Revista de Direito Brasileira | São Paulo, SP | v. 19 | n. 8 | p. 184 - 207 |Jan./Abr. 2018 
percebe-se então que aqui, a preocupação não é tanto pronunciar um argumento melhor, mas sim conferir legitimidade ao tribunal. Exatamente por isso, aponta o professor da Universidade de Tartu (ANNUS, 2004, p. 344), tal prática é muito comum de ser vista principalmente em países que se encontram em períodos de transição democrática, já que há uma necessidade muito forte por parte de jovens cortes constitucionais, em informar que suas decisões estão em consonância com o que vem sendo feito em escala mundial. ${ }^{40}$

Ocorre que de forma complementar, aponta também o jurista estoniano (ANNUS, 2004, pp. 345-346), que para além da questão da legitimidade, três outros motivos, de igual modo, acabam entrando comumente na conta do aspecto institucional. Um deles seria o de que países mais poderosos, econômica, militar e politicamente, como acreditam terem pouco a aprender com outros, acabam se tornando consequentemente menos entusiastas com a incorporação de experiências estrangeiras - isso, aliás, explicaria o porquê de alguns membros da Suprema Corte norte-americana entenderem a análise comparatista como inapropriada para se interpretar a carta magnaianque..$^{41}$ Já uma segunda explicação possível, seria a de que a corte pode ocasionalmente estar preocupada com a responsividade de sua decisão perante a população, motivo pela qual, em tais situações tenderia a adotar somente o material comparado oriundo dos países pertencentes a um grupo de democracias liberais. Por último, destaca ainda que em alguns momentos, os tribunais acabam se motivando a utilizar o direito estrangeiro, não por conta de uma das duas causas expostas anteriormente, mas sim por que se enxergam como parte de uma comunidade internacional de tribunais superiores. ${ }^{42}$

De outra forma, afinal como fora salientado anteriormente, TaaviAnnus não é voz uníssona na tarefa de explicar o porquê as cortes miram experiências alienígenas, vale aqui de igual modo, expor também o catálogo elaborado pela professora norte-americana Vicki Jackson. Que com outras nuances - já que ao mesmo tempo em que elabora uma classificação quanto as diferentes posturas que um tribunal pode adotar frente ao material comparatista, expõe de igual modo os motivos que os levam a tanto - afirma que os tribunais tendem a resistir, convergir ou se engajar no movimento de utilização do material forasteiro, dependendo de algumas circunstâncias que os encaminham para tal direção(JACKSON, 2007, p. 162). Assim, para as cortes resistentes, como seria o caso da SupremeCourtdos Estados Unidos, ${ }^{43}$ em razão de compartilharem uma compreensão de que a lei básica trata-se na verdade da expressão da

seus movimentos não quer tomar uma decisão que venha a ser modificada por outro jogador com autoridade para fazer isso. Em outras palavras, no momento de decidir se age ou não, cada jogador pode não fazer nada se percebe que sua decisão será anulada pelo próximo jogador $[\ldots]$ ”.

${ }^{40}$ Todavia, não se pode também deixar de registrar, que em realidades que não essa, quando do uso do elemento estrangeiro, o efeito pode ser justamente o contrário, isto é, pode se operar uma diminuição da legitimidade da decisão. Assim, como em tais casos, o povo ou as outras instituições tendem a enxergar o ato de se inspirar no que é feito externamente, como uma rendição a um tipo de imperialismo legal, os tribunais, por óbvio, neste tipo de contexto, tendem a não se enveredar por tais caminhos (ANNUS, 2004, p. 345).

${ }^{41}$ Uma das mais comuns citações nesse âmbito, aliás, é a de um trecho do voto do justice Antonio Scalia em Thompson v. Oklahoma (487 U.S 815 1987), nela, assevera o magistrado que “[...] não se pode esquecer que quando se está diante de um caso de controle de constitucionalidade, está se analisando a constituição dos Estados Unidos e nada mais $[\ldots]$ "...

${ }^{42}$ Aliás, isso pode também explicar o porquê do número de citações por outros tribunais a casos decididos pela suprema corte norte-americana estar em declínio, afinal, como a corte ianque pouco se insere neste engajamento acaba mandando sinais de que não se sente como parte desta comunidade (ANNUS, 2004, p. 345).

${ }^{43}$ Tal postura em geral é fruto tanto do chamado American Exceptionalism, termo que teria sido cunhado por Alexis de Tocqueville no ano de 1831, e que se refere à percepção própria dos americanos, de que os Estados Unidos, difere qualitativamente de outras nações, em razão de sua origem única e da evolução histórica e distinta de suas instituições. Como também da influência que exerce a teoria originalista, isto é, do método constitucional de interpretação que busca nas intenções dos foundingfathers o real fundamento para se interpretar o texto fundamental no tempo presente (WHITTINGTON, 2004, p. 599).

Revista de Direito Brasileira | São Paulo, SP | v. 19 | n. 8 | p. 184 - 207 |Jan./Abr. 2018 
identidade nacional (RUBENFELD, 2001, pp. 146), interpretá-la à luz de elementos estranhos ao ordenamento jurídico pátrio não seria nem um pouco recomendável. ${ }^{44}$

Já no que tange aos tribunais convergentes, estes segundo Jackson (2007, p. 164), recebem tal denominação, pois quando das suas decisões é comum que os mesmos, tanto em razão da própria iniciativa, quanto também por conta de elementos normativos, institucionais, ou exógenos, se encaminhem ora ao que determina o direito internacional, ora a um consenso transnacional emergente, ora ainda ao que consideram como sendo a melhor prática adotada entre os países. ${ }^{45}$ Por fim, está-se diante de uma corte engajada (2007, pp. 171-177), quando os juízes, ao menos em princípio, não conseguem resistir ao material de direito comparado, posto que seu manejo se mostra para eles extremamente funcional na prática. Afinal, a experiência não-nacional aqui seria vista pelos magistrados como um importante e necessário mecanismo de teste e compreensão das próprias tradições jurídicas. ${ }^{46}$

Ora, diante disto, vê-se então à luz do esforço descritivo desempenhado por cada um dos autores analisados, que o fato de uma corte decidir por utilizar ou não elementos estranhos ao normativismo na qual se encontra inserida, não é nem de longe acidental. Na verdade, trata-se de um fenômeno que, como em certa medida se tentou demonstrar, pode se fundamentar em intenções muito díspares, exigindo, até mesmo, em alguns momentos, um cuidado meticuloso que pode passar pela ponderação de inúmeras variáveis. Contudo, apesar do entusiasmo para com esta prática, a mesma, ao contrário do que se possa a princípio imaginar, não se revela isenta de críticas. Neste sentido, avaliando-a cum grano salis, é possível, de acordo com o que propõe CherylSaunders (2006, p. 41-42), agrupar as objeções desempenhadas contra a recente impulsão do Direito constitucional comparado, em dois grupos distintos, aquele que questiona a própria legitimidade deste recurso, e o que confere enfoque ao impasse metodológico.

Quanto ao primeiro conjunto, o mesmo possui diferentes matizes, podendo estes serem identificados como a dificuldade cultural; a dificuldade contramajoritária; e a dificuldade institucional. No que tange à crítica de natureza cultural, um raciocínio típico aqui é o que é apresentado por Sarah Harding. A autora (HARDING, 2003, p. 411) afirma que "[...] como há uma conexão próxima entre lei e cultura local, o material estrangeiro, por consequência, possuiria pouco espaço na interpretação judicial [...]", principalmente se considerarmos contextos como o norte-americano, onde há um medo latente de se perder o que os particulariza, ao serem privilegiadas análises comparatistas (HARDING, 2003, p.462). Seria o que Osiatynski (2003, p. 245) chama de "senso de orgulho nacional". De outra forma, compartilham como ideia principal, os adeptos da segunda vertente, a contramajoritária, o fato de que, na verdade, o comparativismo não seria legítimo, posto que sua lógica não se coaduna com a noção de democracia política (ALFORD, 2005, p. 709). Além disso, apontam também aqueles que compõem o quadro da terceira contradita, que como a importação do referencial alienígena pode trazer eventualmente

\footnotetext{
${ }^{44}$ Uma observação, porém, deve ser feita, afinal resistir não é sinônimo de não utilizar. Assim sendo, apesar da jurisprudência norte-americana ser recheada de julgados, onde se percebe nitidamente essa postura recalcitrante, a mesma também possui alguns onde se vê cristalinamente o material comparatista sendo utilizado (JACKSON, 2006, p. 206). É o caso, por exemplo, de O'Malley v. Woodrough(307 U.S. 277 1939), Miranda v. Arizona (384 U.S. 436 1966), Washington v. Glucksberg(521 U.S. 702 1997), e Roper v. Simmons (543 U.S 551 2005).

${ }^{45}$ Um exemplo disso seria o caso da constituição colombiana de 1991, que prevê que os direitos previstos nela devem ser interpretados consistentemente em conjunto com os tratados internacionais de direitos humanos, os quais o país tenha ratificado (JACKSON, 2007, p. 165).

${ }^{46}$ Neste particular pode se citar o caso HerMajesty The Queen v. James Keegstra(3 S.C.R 697 1990), julgado pela SupremeCourtof Canada em 1990. No julgado, onde se discutia se uma previsão do código penal canadense que proibia a promoção de ódio contra grupo identificável feria ou não a cláusula constitucional da liberdade de expressão, tanto a maioria, quanto os dissidentes, passaram boa parte do tempo do julgamento discutindo a jurisprudência norte-americana sobre liberdade de expressão, para aí sim fundamentarem a tese que defendiam. A justificativa para isso, na ocasião, foi a de que era notável a aproximação que possuíam Canadá e Estados Unidos no tocante à proteção constitucional daquele direito fundamental, o que não poderia ser negligenciado.
} 
riscos ao equilíbrio que existe entre as instituições de um dado sistema, tal atividade, como consequência, não seria interessante (HARDING, 2003, p. 412).

Em um plano diverso de tais vieses, ao se levar em conta as críticas erigidas a partir do prisma metodológico, as tendências passíveis de serem identificadas aqui acabam sendo reunidas em duas. Há aquelas formuladas na condição de admoestações, e há outras que se centram em questões substantivas preocupadas ora com a ameaça à integridade do sistema doméstico, ora com o problema da irracionalidade que permeia o uso do material forasteiro pelas cortes. Em relação as que procuram se expressar através de conselhos, destacam-se, neste particular, tanto a que se concentra em indicar a relevância do contexto para a importação de experiências ádvenas (OSIATYNSKI, 2003, p. 262), ${ }^{47}$ quanto a que, por sua vez, frisa a circunstância de que os operadores do Direito não possuem capacitação suficiente para se valerem do cotejamento (RAHDERT, 2007, p. 665). Já no tocante as colocações de natureza substantiva, a tese central dirigida primeiro por aqueles que se propõe a refletir sobre a consistência e a coerência interna do ordenamento jurídico, ${ }^{48}$ é a de que o recurso ao argumento de direito comparado, abre espaço para que a constituição perca seu papel de instrumento de estabilização política e social (HARDING, 2003, p. 454). ${ }^{49}$ Por outro lado, em segundo lugar, para os que trabalham no âmbito da carência de racionalidade, a preocupação medular destes passa pelo fato de que como há uma verdadeira esquizofrenia de teorias comparatistas (ALFORD, 2005, p. 711), isso contribui para que não haja um único e coerente modo dos tribunais se valerem das referências alienígenas, abrindo-se então espaço para que o uso de tal recurso seja auto-orientado. ${ }^{50}$

Ocorre que à luz do que chama à atenção David Fontana (2001, p. 562), uma vez que as cortes continuam a se socorrer de elementos forasteiros sem maiores elucubrações sobre se tal atividade é legítima ou não, as disputas acadêmicas neste domínio, que, diga-se de passagem, até o momento ainda não produziram também qualquer consenso, já que existem opiniões respeitáveis para ambos os lados (DAMMANN, 2002, p. 516), acabaram se mostrando no geral pouco construtivas. Isso, contudo, não significa dizer que o mesmo se dá em relação as últimas colocações postas acima, quais sejam, as de cunho metodológico. Afinal, é justamente partir do reconhecimento dos óbices apontados pelos autores neste curso, que foram pensadas algumas propostas tendentes a cobrir o vazio que ainda hoje existe, sobre como os juízes deveriam proceder de forma racional e justificada, quando da utilização de experiências estrangeiras no desenvolvimento da interpretação da lei maior.

Assim, longede estar sedimentada, a discussão sobre o método no Direito comparado continua ainda hoje a levantar inúmeros questionamentos. ${ }^{51} \mathrm{~A}$ diferença, contudo, no âmbito constitucional, fica pelo fato de que a mesma, assim como vem sendo visto até o momento, passa a ser temperada também pela utilização do arcabouço forasteiro pelas supremas cortes. E em tal âmbito, o que se vê é a existência de pelo menos duas posições básicas: uma capitaneada por

\footnotetext{
47 “"...] As condições sociais não apenas possuem um importante papel no processo de empréstimo, mas podem até mesmo decidir o sucesso ou a falha de transplantes constitucionais. Algumas experiências que funcionam muito bem em um determinado contexto social, podem ser inúteis ou até mesmo destrutivas em outros [...]" (OSIATYNSKI, 2003, p. 262).

${ }^{48}$ Como indica Mark Rahdert (2007, p. 589), os que advogam esta proposição entendem que "[...] o uso do referencial estrangeiro pelas cortes corrói o controle do povo sobre o que suas leis e sua constituição significam, bem como sobre o que a política deve ser [...]".

${ }^{49}$ Isso por que na linha do que afirma Frederick Schauer (1997, p. 1376), ao se utilizar excessivamente o direito comparado, a constituição escrita perde sua força de estabilização, algo que por consequência, permite que muitos problemas se mantenham excessivamente incertos.

${ }^{50}$ No mesmo sentido, segundo Christopher McCrudden (2000, p. 507), "[...] há cada vez mais preocupações expressas pelos comentaristas acadêmicos à respeito do substancial 'cherry picking' de jurisdições a citar, de que as jurisdições escolhidas serão sempre aquelas que são suscetíveis de apoiar a conclusão inicialmente pensada, abrindo margem para a tomada de decisões arbitrárias e julgamentos ilegítimos [...]".

${ }^{51}$ Segundo Vernon Palmer (2004, p. 01) as discussões em torno do método no direito comparado ainda hoje continuam a ser uma boa cura para a insônia, já que o que há neste plano é um verdadeiro caos.
} 
Mark Tushnet e outra por SujitChoudhry. Enquanto o primeiro, parte do pressuposto de que o moderno direito constitucional comparado não se preocupou em criar métodos próprios, pois recebeu como herança àqueles utilizados pela ciência do Direito comparado geral, sendo os mesmos perfeitamente utilizáveis, inclusive, pelos tribunais (TUSHNET, 2006, p. 67), o segundo critica o fato de que nenhuma das metodologias existentes se direcionou para a tarefa de interpretação da carta magna (CHOUDHRY, 1999, p. 833). Considerando tais posições, o escopo das linhas seguintes será justamente o de demonstrar de que forma estes são encaminhados pelos autores.

Assim, no que se refere ao direcionamento dado por Mark Tushnet, o autor oferece um mapa conceitual com ilustrações de três métodos que, ${ }^{52}$ segundo ele, as investigações no âmbito do direito constitucional comparado podem-se valer. ${ }^{53} \mathrm{O}$ primeiro seria o chamado universalismo normativo (TUSHNET, 2006, p. 68), ${ }^{54}$ onde o raciocínio seria bem simples. Afinal, como o próprio constitucionalismo implica na assunção de alguns princípios fundamentais, a comparação, portanto, se daria entre as diferentes versões que podem ser encontradas destes postulados. ${ }^{55}$ Já quanto à segunda metodologia, conhecida como funcionalista, de acordo com Tushnet (2006, p. 72), nesta o pesquisador ao observar distintos arranjos ou práticas constitucionais ao redor do mundo, procuraria por equivalentes funcionais de um dado instituto, a fim de determinar quais seriam as melhores soluções. Quer dizer, levando-se em conta, por exemplo, o fato de que praticamente todas as nações democráticas possuem uma cláusula insculpida em seus textos constitucionais, responsável por lidar com situações de guerra ou de emergência doméstica, e capazes até mesmo de ameaçar eventualmente a própria continuidade do Estado, uma pesquisa funcionalista com o fito de determinar quais são as mais acertadas, e também quais são os mais controversos processos neste particular, faria as seguintes indagações: ${ }^{56}$

"[...] o detalhe e as circunstâncias do procedimento incentivam a participação do legislador e do Executivo na tomada de decisão? Ou pelo contrário, não oferece detalhes, permitindo ao executivo a ação unilateral? Por exemplo, podem as disposições de um país correrem o risco de que o Executivo afirme

\footnotetext{
${ }^{52}$ A parte destes, vale registrar que em outra oportunidade, Tushnet (1999, p. 1227) chama a atenção ainda para uma quarta estratégia de uso do direito constitucional comparado, a qual ele denomina de bricolage. De acordo com o professor de Harvard (TUSHNET, 1999, p. 1256), a mesma seria fácil e plenamente aplicável tanto nos processos de edição de novos textos políticos, quanto nos de sua interpretação, uma vez que o ponto de partida aqui seria entender, que sejam os redatores, sejam os intérpretes de uma lei fundamental, atuam no desempenho de suas funções, sempre enquanto verdadeiros bricoleur, quer dizer, sob a pressão de darem uma resposta, acabam se agarrando aleatoriamente a qualquer solução próxima aos problemas imediatos que enfrentam, e em tal caso, sem dúvidas, uma delas acaba sendo percebida a partir do material comparado (TUSHNET, 1999, p. 1264).

${ }^{53}$ Para Tushnet (2006, p. 68), cada método possui seus benefícios e limitações, assim não há o que se falar sobre a superioridade de um ou de outro.

54 A dificuldade aqui está no fato de que "[...] este método opera em um nível muito alto de abstração. Assim, podemos supor que existem princípios universais de liberdade e justiça, mas também podemos estar razoavelmente confiantes de que tais princípios não são tão facilmente captados em se tratando, por exemplo, de liberdade de expressão ou de igualdade [...]" (TUSHNET, 2006, p. 74).

${ }^{55}$ Um exemplo capaz de elucidar bem esse método, e que é apresentado por Tushnet, diz respeito à regulação do hate speech. De acordo com o autor (TUSHNET, 2006, pp. 71-72) “[...] os defensores de uma maior regulação do discurso do ódio nos Estados Unidos, muitas vezes referem-se a normas constitucionais transnacionais, como a que possui o Canadá sobre a mesma matéria, para defender a proposta de que a regulamentação do hate speech não deve ser tratada como inconstitucional à luz da primeira emenda. Eles argumentam com razão, que o fato de democracias liberais modernas regulamentarem o discurso do ódio sem que caminhem para regimes tirânicos, e onde, inclusive, o governo se engaja em tal controle, mostra que a existência de regulamentos do discurso do ódio é compatível com as normas gerais de liberdade de expressão [...]".

${ }^{56}$ Tais questões indicam "[...] que análises funcionalistas irão olhar como disposições constitucionais operam realmente no mundo real, bem como farão inferências sobre um bom projeto constitucional, a partir das disposições percebidas como as que funcionam melhor [...]" (TUSHNET, 2006, pp. 73-74).
}

Revista de Direito Brasileira | São Paulo, SP | v. 19 | n. 8 | p. 184 - 207 |Jan./Abr. 2018 
plausivelmente que é necessário estender a emergência para além do período autorizado pelo Legislativo, por que as circunstâncias assim o requerem? A falta de detalhes incentiva a negociação política entre o Legislativo e o Executivo, ou pelo contrário, ou dá ao Executivo recursos para argumentar que sua ação sem respaldo do Legislativo é constitucionalmente permitida já que não expressamente proibida pela constituição? É uma exigência constitucional que o Legislativo participe da limitação do número de ocasiões nos quais a emergência pode ser declarada ? Ou, pelo contrário, tal disposição permite que o Executivo passe por cima do Legislativo apelando ao povo para que repudiem a legislatura que, não é capaz de reconhecer e responder a emergência que a nação enfrenta ? [...]" (TUSHNET, 2006, p. 73).

Na sequência, em relação a terceira e última abordagem, a qual Tushnet (2006, p. 68) dá o nome de contextualista, esta, segundo o mesmo, pode se desenvolver em duas variantes: o contextualismo simples e o expressivismo. Em relação a primeira categoria, esta põe ênfase no fato de que a constituição só pode ser compreendida se estiver associada ao seu contexto. ${ }^{57} \mathrm{E}$ exatamente por assim ser, estudos comparatistas realizados à luz deste método podem se apresentar com a roupagem, por exemplo, de pesquisas etnográficas, históricas, ou ainda mais frequentemente, doutrinárias e institucionais (TUSHNET, 2006, p. 76). Já por outro lado, no que tange a segunda aproximação, nesta a constituição é tida como produto da história de cada nação, e expressão do seu caráter distintivo (TUSHNET, 1999, p. 1248). Sendo assim, uma investigação expressivista então, iria contrastar os autoentendimentos dos diferentes países, ${ }^{58}$ com o intuito de refinar a compreensão dos valores da própria tradição jurídica. ${ }^{59}$

De modo diverso, já que sua proposta além de prescritiva se centra de maneira exclusiva na utilização do direito comparado durante a interpretação constitucional, SujitChoudry (1999, p. 830) apresenta uma classificação tripartite, segundo a qual os métodos seriam para ele, o universalista, o genealógico e o dialógico. No que toca ao primeiro deles, a exortação feita é para que "[...] os tribunais não prestem tanta atenção às particularidades jurídicas nacionais, ao se envolverem na interpretação constitucional [...]" (CHOUDHRY, 1999, p. 845). Afinal, ao serem suprimidas as diferenças que existem entre os sistemas jurídicos, ${ }^{60}$ e que são oriundas principalmente dos percursos históricos nos quais cada país se conduz, abre-se caminho para que

\footnotetext{
${ }^{57}$ Afinal, “[...] constituições combinam normas substantivas, tais como o compromisso com a liberdade de expressão e a igualdade, com arranjos institucionais, como o federalismo e o governo parlamentar. As normas substantivas são implementadas dentro de tais arranjos, e alguns arranjos, por vezes, se mostram mais compatíveis com algumas interpretações das normas substantivas do que outros [...]" (TUSHNET, 2006, p. 76).

${ }^{58}$ Um exemplo apresentado por Tushnet (2006, p. 80) está expresso na comparação dos casos U.S. v. Burns (S.C.R. 283, 2001), julgado pela corte constitucional canadense e o Stanford v. Kentucky (492 U.S. 361, 1989), julgado pela suprema corte norte-americana. Enquanto no primeiro o tribunal achou por bem extraditar um cidadão norteamericano acusado de um crime de homicídio, desde que, porém, os Estados Unidos assumissem que não o levariam a pena de morte. No segundo, a SupremeCourt afirmou que discutia os padrões de decência dos Estados Unidos e não de outros países, razão pela qual era constitucional a pena de morte de jovens entre 16 e 18 anos. Uma análise expressivista aqui perceberia como há uma auto-consciência voltada para o exterior no Canadá, e como a mesma é introspectiva nos Estados Unidos.

${ }^{59}$ A dificuldade da abordagem contextualista, em suas duas vertentes, é a de que ambas podem nos levar a percepção errada de que um determinado arranjo é necessário, estando ele inserido dentro de seu próprio contexto. Contudo, a extensão das restrições impostas pela conjuntura no qual ele está inserido, pode ser tanta, que o conjunto de opções onde ele pode ser aplicado, acaba se reduzindo a apenas um lugar, qual seja, onde ele já se encontra (TUSHNET, 2006, p. 81).

${ }^{60}$ De acordo com Choudhry, $(1999$, p. 940) "[...] ideias universalistas podem ser obtidas a partir de qualquer sistema jurídico, a única exigência é que o sistema para onde aponta a pesquisa comparatista compartilhe uma disposição constitucional em particular [...]".
}

Revista de Direito Brasileira | São Paulo, SP | v. 19 | n. 8 | p. 184 - 207 |Jan./Abr. 2018 
às cortes descubram princípios que transcendem toda e qualquer ordem, ${ }^{61}$ e que podem, figurando como argumento, lhes auxiliar na tomada de decisões (CHOUDHRY, 1999, p. 869).

Por outro lado, quanto ao segundo modelo interpretativo, o genealógico, o pressuposto para que o mesmo seja aplicado é a relação familiar ${ }^{62}$ que deve existir entre dois ou mais sistemas jurídicos (CHOUDHRY, 1999, p. 907). Caso o parentesco seja por subordinação, a interpretação será em sentido forte, ${ }^{63}$ já, por outro lado, se a ligação for apenas por conta de laços históricos comuns, a interpretação será de curso fraco. Ora, considerando o fato de que o primeiro tipo é de mais difícil ocorrência, já que depende da circunstância de haver dependência legal entre ordenamentos, Choudhry, (1999, p. 908) então, acaba se concentrando no segundo tipo, e exatamente por isso, identifica três passos pelos quais o intérprete deve percorrer argumentativamente neste âmbito para o sucesso da investigação. Primeiro, ele deve identificar o ancestral comum, quer dizer, identificar o "pai jurídico" que fundamente o seu próprio ordenamento e aquele a que está a observar. Segundo, deve demonstrar a existência de uma cultura compartilhada, o que em termos legais, significa que ambos os sistemas precisam compartilhar uma regra legal, ou um conjunto de regras que têm origem no mesmo ancestral. Feito isso, combinando as reivindicações de herança e de ancestralidade, aí sim seria estabelecida, como corolário, a relevância e a legitimidade do material de direito comparado a ser usado pelo tribunal. ${ }^{64}$

Por último, no que toca o terceiro método, o dialógico, ${ }^{65}$ o coração deste reside no reconhecimento do que de fato significa a pretensão de "diferença constitucional". Para Choudhry (1999, p. 890), como uma carta política só é exclusiva se posta em comparação com outras que compartilham algumas características que essa não possui, o objetivo, portanto, de realizar comparações entre as mesmas, só pode ser o de adquirir uma maior consciência e uma melhor compreensão sobre o que as difere ou aproxima.Contudo, reconhece o autor (CHOUDHRY, 1999, pp. 891-892), para o sucesso dessa empreitada, a reflexão interpretativa realizada pelo magistrado deve seguir três etapas. A primeira seria usar a experiência comparada como um meio de identificar os pressupostos da própria ordem constitucional da qual o intérprete faz parte. ${ }^{66}$ A segunda, confrontar o material interno e o externo, procurando justificar as próprias escolhas que inevitavelmente privilegiam alguns pontos de vista em detrimento de outros. E,

${ }^{61}$ É importante destacar, porém, que quanto maior for a diversidade normativa, mais difícil será criar argumentos universalistas (CHOUDHRY, 1999, p. 941).

${ }^{62}$ Exatamente por isso, Choudhry (1999, p. 938) assume que o mesmo é restrito a um pequeno conjunto de contextos legais.

${ }^{63}$ Segundo SujitChoudhry (1999, p. 908) "[...] a câmara dos lordes e os vários tribunais nacionais de recurso no sistema legal do império britânico exemplificam esta reivindicação. Os sistemas jurídicos nacionais dentro do império britânico eram nominalmente independentes dos tribunais da Inglaterra e aplicavam suas próprias leis. No entanto, cabia apelação das decisões tomadas, por exemplo, pela Suprema Corte do Canadá, pelo Tribunal Superior da Austrália e pela Divisão de Apelação do Supremo Tribunal Sul-Africano, para a câmara dos lordes, através do PrivyCouncil $[\ldots]$ "..".

${ }^{64}$ Duas, porém, são as críticas elencadas pelo professor da Universidade de Nova York (CHOUDHRY, 1999, p. 940), a primeira é a de que nem sempre é fácil comprovar a genealogia de dois ou mais sistemas jurídicos, e a segunda (CHOUDHRY, 1999, p. 943), diz respeito ao fato de que as decisões de hoje acabam demandando das cortes, que estas mirem o passado, ao invés de forjarem um novo começo.

65 Este tipo de interpretação, segundo o autor, permite um tribunal se valer do direito comparado sem "internacionalizar" sua cultura local, bem como, permite que um tribunal aprenda com a experiência estrangeira sem a necessidade de assimilar a sua jurisprudência (CHOUDHRY, 1999, p. 945).

${ }^{66}$ Como salienta SujitChoudhry $(1999$, p. 890) “[...] o tribunal examina a jurisprudência e a doutrina comparada, não primariamente para obter uma imagem fiel de como se encontra legalmente uma outra jurisdição, mas sim para identificar os pressupostos que se encontram por debaixo. Mayo Moran, perspicazmente argumentou que, por exemplo, sob a jurisprudência norte-americana acerca do hate speech, encontra-se um medo de um estado totalitário e uma concepção altamente individualista do significado de liberdade. Ora, no processo de articular os pressupostos da jurisprudência estrangeira, um tribunal inevitavelmente descobre a sua própria [...]".

Revista de Direito Brasileira | São Paulo, SP | v. 19 | n. 8 | p. 184 - 207 |Jan./Abr. 2018 
finalmente, na terceira e última, diante das diferenças e semelhanças postas, o tribunal optaria por rejeitar o elemento forasteiro, ou mesmo por incorporá-lo, ${ }^{67}$ a depender da situação.

Acontece, contudo, que em razão de tanto a proposta elaborada por Tushnet, quanto a engendrada por Choudhry, não guardarem consigo a marca da obrigatoriedade, isto é, levando-se em conta o fato de que os dois inventários não se constituem enquanto sendo de observância compulsória pelos tribunais. E ainda, o fato de que cada corte, é responsável, como órgão de soberania, pela criação e desenvolvimento de sua própria dinâmica. Assim, existe sempre o risco, e a doutrina atual ainda não conseguiu resolver esse problema, dos tribunais ao invés de exporem de forma racional, justificada e coerente as experiências estrangeiras das quais se utilizam, agirem de forma descompromissada equiçá direcionada (LOIS \& MARQUES, 2015).

\section{CONCLUSÃO}

O presente trabalho teve por objetivo apresentar algumas notas sobre os principais temas queno passado movimentaram e que nos dias correntes movimentam,os autores que se dedicam aosestudosem direito constitucional comparado. Nesta senda, o queinicialmente se quis demonstrar foi quea doutrina ao se perder entre a discussão sobre se o direito comparado era método ou ciência, no longo prazo,porque issoencaminhouos pesquisadoresa um nível de abstração e cansaço intelectual sem precedentes, daí a frente, artigos e manuais passaram a apenas reproduzir o referido debate e indicar o partido tomado. O que feito pelos teóricos do clássico direito constitucional comparado, os permitiu se dedicar ao debate daquilo que para eles eram osprincipais assuntos que mereciam à atenção, no caso, para que se compara ou o problema da finalidade, que seria conhecer e realizar objetivos outros que não o uso por cortes constitucionais. O que se compara ou o problema do objeto, onde se chega a conclusão de que embora o texto magno seja o material ordinário das pesquisas, não se pode deixar de atentar parao fato de que o mesmo não existe sem uma conexão com a realidade social e que existem vários locais em que prevalecem regras consuetudinárias.Epor último, como comparar ou o impasse sobre o método, oportunidade em que se reconhece que mesmo estes sendo muitos, no geral percorre-se três momentos lógicos, o conhecimento, a compreensão ea comparação stricto sensu, para ao fim e ao cabo classificar as experiências constitucionais e formar a partir delas um material de consulta.

Feitos tais destaques, considerandoo renovado ímpeto que tem caracterizado a maior parte dos trabalhos atuais, qual seja, o de que há um uso crescentedo referencial estrangeiro pelas supremas cortes ao redor do mundo. O presente trabalho em arremate, partiu ainda para pontuar neste âmbito asindagações que colonizam o pensamento de autores contemporâneos, quais sejam, em qual ocasião, ou diante de questões complexas. Por qual motivo, ou por um sem número destes, que por falta de diálogo entre os teóricos chegam até a se sobrepor. E de que forma,ou segundo a herança do Direito comparado geral e por intermédio de novidosas particularidades.Para enfim, chamar a atenção à preocupação de que pela falta de delimitados e bem esclarecidos procedimentos, há o risco do direcionamento das experiências alienígenas no sentido da intenção do julgador.

\footnotetext{
67 “[...] nos casos de diferença constitucional, se o tribunal rejeita suposições estrangeiras e afirma a sua própria, o valor deste exercício foi o de aumentar a sua consciência e compreensão da diferença constitucional, que por sua vez, irá moldar e guiar a interpretação. Já por outro lado, nos casos de semelhança constitucional, se a mesma é abraçada, a interpretação dialógica fundamenta a legitimidade da experiência importada, que passa a ser aplicada como se lei fosse [...]" (CHOUDHRY, 1999, p. 891).
} 


\section{REFERÊNCIA BIBLIOGRAFICA}

ALFORD, Roger. In search of a theory for constitutional comparativism. In: UniversityofCalifornia Law Review. No 52, 2005.

ALMEIDA, Carlos Ferreira de; \& CARVALHO, Jorge Morais. Introdução ao direito comparado. Coimbra: Almedina, 2013.

ANCEL, Marc. Utilidade e métodos do Direito Comparado. Porto Alegre: Sérgio Antônio Fabris, 1980.

ANNUS, Taavi. Comparative constitutional reasoning: the law and strategy of selecting the right arguments. In: Duke Journal of Comparative and International Law. Vol. 14, 2004.

BLAGOJEVIC, Borislav. Le Droitcomparé: méthod ou science? In: RevueInternationale de DroitComparé. No 04, 1953.

CAÑIZARES, Felipe de Solá. Introducción al Derecho Comparado. Barcelona: Instituto de Derecho Comparado, 1954.

CANOTILHO, José Joaquim Gomes. Direito constitucional e teoria da Constituição. Coimbra: Almedina, 2003.

CAPITANT, Henri. (Org.). VocabulaireJuridique. Paris: Pressesuniversitaires de France, 1930.

CHOUDHRY, Sujit. Globalization in search of justification: toward a theory of comparative constitution interpretation. In: Indiana Law Journal. Vol. 74, 1999.

Migration as new metaphor in comparative constitutional. In: CHOUDHRY, Sujit. (Org. ). The migration of constitutional ideas. Cambridge: Cambridge University Press, 2006.

CONSTANTINESCO, Leontin-Jean. Tratado de Direito Comparado: introdução ao direito comparado. Rio de Janeiro: Renovar, 1998.

DAMMANN, Jens. The role of comparative law in statutory and constitutional interpretation. In: St. Thomas Law Review. Vol. 14, 2002.

DANTAS, Ivo. Direito constitucional comparado. Vol. I. Teoria do Direito Comparado (Introdução, Teoria e Metodologia). Rio de Janeiro: Renovar, 2006.

ESKRIDGE, William. Reneging on History?: playing the court/congress/president civil rights game. In: California Law Review. Vol. 79, 1991.

FONTANA, David. Refined comparativism in constitutional law. In: University of California Law Review. No 49, issue 2, 2001.

GARCÍA-PELAYO, Manuel. Derecho constitucional comparado. Madrid: Alianza Editorial, 1984. 
GUTTERIDGE, Harold Cooke. Comparative Law: an introduction to the comparative method of legal study and research. Cambridge: Cambridge University Press, 1949.

HARDING, Sarah. Comparative reasoning and judicial review. In: The Yale Journal of International Law. Vol 28, 2003.

JACKSON, Vicki. Ambivalent resistance and comparative constitutionalism: opening up the conversation on proportionality, rights and federalism. In: Journal of Constitutional Law. Vol. 1, issue 3, 1999.

Constitutional law and transnational comparisons: the youngstown decision and american exceptionalism. In: Harvard Journal of Law \& Public Policy. Vol. 30, nº 01, 2006.

. Transnational challenges to constitutional law: convergence, resistance, engagement. In: Federal Law Review. Vol. 35, nº 02, 2007.

LOIS, Cecilia Caballero; MARQUES, Gabriel Lima. O Supremo Tribunal Federal e o argumento de direitoconstitucionalcomparado: umaleituraempírica a partir dos casos de liberdade de expressão no Brasil. In: Direito, Estado e Sociedade. № 47, 2015.

MARQUES, Gabriel Lima. Entre o clássico e contemporâneo: uma (re) leitura dos fundamentos históricos do direito constitucional comparado. In: Revista do Direito Público. V. 09, $\mathrm{N}^{\circ} 03$, 2014.

MCCRUDDEN, Christopher. A common law of human rights? Transnational judicial conversations on constitutional rights. In: Oxford Journal of Legal Studies. Vol. 20, nº 04, 2000.

MIRANDA, Jorge. Notas para uma introdução ao direito constitucional comparado. Coimbra: Coimbra Editora, 1970.

. Manual de Direito Constitucional. Volume I. Coimbra: Coimbra Editora, 1990.

MIRKINE-GUETZEVICH, Boris. I metodidistudiodeldirittocostituzionalecomparato. In: Il Politico, rivista italiana discienzepolitiche, 1951.

OBIORA, LeslyeAmede. Reconstituted consonants: the reach of a "common core" analogy in human rights. In: HastingsInternational\&Comparative Law Review. No 21, 1998.

OSIATYNSKI, Wiktor. Paradoxes of constitutional borrowing. In: International Journal of Constitutional Law. Vol. 01, $\mathrm{n}^{\circ}$ 02, 2003.

PALMER, Vermon. From lerotholi to lando: some examples of comparative law methodology. In: Global JuristFrotiers. Vol. 4, issue 2, 2004.

PEGORARO, Lucio. La utilización del derecho comparado por parte de las cortes constitucionales: un análisis comparado. In: MAC-GREGOR, Eduardo Ferrer; \& LARREA, Arturo Zaldívar Lelo de. (Orgs.). La ciencia del derecho procesal constitucional: estudios en homenaje a Héctor Fix-Zamudio. Tomo II. Ciudad del México: UNAM, 2008. 
RAHDERT, Mark. Comparative constitutional advocacy. In: American University Law Review. Vol. 56, issue 3, 2007.

RUBENFELD, Jed. Freedom and time: a theory of constitutional self-government. Yale: Yale University Press, 2001.

RUFFIA, Paolo Biscaretti di. Introduzione al Dirittocostituzionalecomparato. Milano: Giuffrè, 1974.

SACCO, Rodolfo. Legal formants: a dynamic approach to comparative law. In: American JournalofComparative Law. Vol. 39, 1991.

Introdução ao Direito Comparado. São Paulo: Revista dos Tribunais, 2001.

SAUNDERS, Cheryl. The use and misuse of comparative constitutional law. In: Indiana Journal of Global Legal Studies. Vol. 13, 2006.

SCARCIGLIA, Roberto. Introducción al derecho constitucional comparado. Madrid: Dykinson S.L, 2011.

SCHAUER, Frederick. On extrajudicial constitutionalinterpretation. In: Harvard Law Review. Vol. 110, nº 07, 1997.

Authority and authorities. In: Virginia Law Review. N 94, 2008.

SILVA, José Afonso da. Direito constitucional comparado e processo de reforma do Estado. In: BONAVIDES, Paulo; LIMA, Francisco Gérson Marques de; \& BEDÊ, Fayga Silveira. Constituição e Democracia: estudos em homenagem ao professor J. J. Gomes Canotilho. São Paulo: Malheiros, 2006.

SMITS, Jan. Comparative law and its influence on national legal systems. In: REIMANN, Mathias; \& ZIMMERMANN, Reinhard. (Orgs.). The Oxford handbook of comparative law. Oxford: Oxford University press, 2006.

TUSHNET, Mark. The possibilities of comparative constitutional law. In: Yale Law Journal. $\mathrm{N}^{\mathrm{o}}$ $108,1999$.

Some reflections on method in comparative constitutional law. In: CHOUDHRY, Sujit. (Org. ). The migration of constitutional ideas. Cambridge: Cambridge University Press, 2006.

VERGOTTINI, Giuseppe de. Derecho constitucional comparado. Mexico D.F: UNAM, 2004.

WEINRIB, Lorraine. Constitutional concepts and constitutional comparativism. In: TUSHNET, Mark; \& JACKSON, Vicki. Defining the field of comparative constitutional law. Connecticut: Praeger, 2002.

WHITTINGTON, Keith. The new originalism. In: Georgetown Journal of Law and Public Policy. Vol. 2, 2004. 